World Applied Sciences Journal 15 (2): 271-278, 2011

ISSN 1818-4952

(C) IDOSI Publications, 2011

\title{
Effects of Managerial Ties and Appropriability Regimes on Open Innovation
}

\author{
M. Muzamil Naqshbandi and Sharan Kaur \\ Department of Business Strategy and Policy, Faculty of Business and Accountancy, \\ University of Malaya, Kuala Lumpur, Malaysia
}

\begin{abstract}
In today's globalized world, firms are increasingly seen shifting from the traditional innovation model which relied on a firm's internal R\&D to the more porous open innovation paradigm which utilizes resources both internal and external to a firm to come up with innovations. However success in the open innovation paradigm is contingent upon some internal and external factors of a firm. This conceptual paper first discusses how one such internal factor - managerial ties - impacts the success of open innovation. Second, this paper looks at the moderating role of an external factor - appropriability regimes - on the relationship between managerial ties and success of open innovation. We propose that building managerial ties is important for the creation of open innovation since open innovation requires exploration and exploitation of external resources. We further posit that presence of strong appropriability regimes is crucial to reap the benefits of managerial ties in the open innovation model and that in presence of weak appropriability regimes, managerial ties may not produce results as valuable. Propositions are developed, managerial implications underscored and future research directions highlighted.
\end{abstract}

Key words: Open innovation $\cdot$ Managerial ties $\cdot$ Regimes of appropriability

\section{INTRODUCTION}

The changing global conditions have in many ways predisposed firms to make a shift from the way they innovated and gained competitive advantage by relying on internal research and development within the boundaries of the firm, to a greater reliance on the resources lying not only inside but outside the firm boundaries. Open innovation has thus emerged as an alternative model of innovation wherein firms commercialize both external and internal ideas and technologies and use both external and internal resources. In an open innovation process, projects can be launched from internal or external sources and new technology can enter at various stages [1]. Some of the reasons for firms to enter into collaborative relationships are to improve innovation, increase speed to market and reduce the costs of internal vertical integration. When the partner firms share information, it improves their efficiency and helps them focus on joint opportunity recognition [2]. Organizations create value externally by acquiring skills and knowledge from partners to complement the internal capabilities of their organizations [3]. As a result of collaboration efforts of the partnering firms, a heady mix of talent and expertise from people working together in new ways often stimulates innovation. This has further been made easier by the advent of information technology that has enabled better coordination of alliance partner value chains and greater integration as demanded by the new global market forces [4].

However several challenges come in the way of open innovation process. For instance, how do firms explore and choose right firm partners collaborating with whom will create value for the firm. Open innovation relies first on identification of proper and compatible knowledge sources and later their exploitation to create value. How do firms identify these knowledge sources? How do firms interact with the potential knowledge sources and how does the process of open innovation start? To overcome these and other challenges that firms in the open innovation paradigm face especially during the infancy stage, we propose that ties of managers are crucial to deal with such problems. Several studies have shown the positive relation between managerial ties and firm performance $[5,6]$. In many cases, particularly in transition economies, managerial ties can even help a firm gain

Corresponding Author: M. Muzamil Naqshbandi, Department of Business Strategy and Policy, Faculty of Business and Accountancy, University of Malaya, Kuala Lumpur, Malaysia.

${ }^{1}$ An earlier version of this paper was presented at the $16^{\text {th }}$ IBIMA conference held from 29-30 June, 2011 in Kuala Lumpur, Malaysia 
competitive advantage over its competitors. This paper thus proposes that managerial ties facilitate innovation in the open innovation paradigm. Managerial ties as studied in this paper are three-pronged: ties with managers at other firms, ties with government officials and ties with universities and other research centers.

Managerial ties alone, however, cannot lead to success in the open innovation paradigm. A firm's favorable internal resources and conditions may not be enough to lead it to successful open innovation. Therefore, besides managerial relations, the success of a firm in general is contingent upon its understanding of the external environment to survive volatile times [7]. Before creating any kind of innovation, it is important for a firm to measure its potential benefits and check whether it can appropriate the results of its innovative activities. The appropriation of results of innovative activity is vital for innovative companies because it enables them to enjoy the pro?ts their innovations generate [8]. Therefore, surveying the appropriability regimes of the industry can help determine ex ante the benefits of potential open innovations.

The remainder of this paper takes the following structure. The second section reviews the related literature on open innovation and highlights its dimensions. It also sums up the relevant literature on managerial ties and appropriability regimes. The third section discusses the proposed methodology and scale development to take forward and test the hypotheses developed in this paper. The fourth section provides a discussion of the variables of interest and their relationship with each other. The last section provides conclusion, implications and future research directions.

\section{Literature Review}

Open Innovation: Open innovation has become one of the hottest topics in innovation management [9]. The term Open Innovation was introduced and popularized by Henry Chesbrough, a Berkeley professor at University of California. Chesbrough defines open innovation as:

"the use of purposive inflows and outflows of knowledge to accelerate internal innovation and expand the markets for external use of innovation, respectively. Open Innovation is a paradigm that assumes that firms can and should use external ideas as well as internal ideas and internal and external paths to market, as the firms look to advance their technology" [10].
In one of his definitive articles, Chesbrough [11] lists down the contrasting principles of closed innovation and open innovation. According to Chesbrough, firms in the closed innovation model assumes that: a) the smart people in our field work with us, b) to profit from, R\&D, we must discover, develop and ship ourselves, c) if we discover it ourselves, we will get it to the market first, d) If we are to commercialize an innovation, we will win, e) if we create the most and the best deals in the industry, we will win and, f) we should control our Intellectual Property so that our competitors do not profit from our ideas. On the other hand, firms operating in the open innovation paradigm assume that: a) not all smart people work inhouse and thus there is a need to tap into external knowledge, b) external research and development can generate significant value to us, c) research does not need to originate from our internal work to be profitable for us, d) a strong business model is more important than bringing products to the market first, e) internal as well as external ideas are essential to win and, f) we can capitalize on our own IP and we should buy others' IP when needed [11].

Chesbrough [11] explains how in the $20^{\text {th }}$ century firms profited from innovations that were outcomes of heavy investments in internal research and development of firms. However with the changing times towards the end of the $20^{\text {th }}$ century, a number of factors combined together to cause the closed innovation process to break up in the United States. The two main such factors were: 1) Rise in the number and mobility of knowledge workers and 2) growing availability of private venture capital. While the increase in the number and mobility of knowledge workers made it difficult for companies to control their proprietary ideas and expertise, the increased availability of private venture capital helped finance new firms and commercialize new ideas that would otherwise be found useless or less useful in corporate research labs. This paved the way for more open innovation [11].

Open innovation incorporates explicitly the business model as the source of value creation and value capture, helping a firm sustain its position in the industry while at the same time sharing the task of value creation across industry value chain (Chesbrough, et al., 2006). In an open innovation paradigm, valuable ideas may come from inside or outside the company and can go to market from inside or outside the company as well. This approach places external ideas and external paths to market on the same level of importance as that reserved for internal ideas and paths to market during the Closed Innovation era [11]. 
Chesbrough et al. [10] consider the open innovation model as the antithesis of the traditional, vertically integrated model wherein internal research and development (R\&D) efforts of a firm lead to products developed internally and distributed thereafter One of the limitations of the closed innovation model is that monolithic organizations that carry out business in isolation develop fragmented linkages and poor interfaces [12].

Dimensions of Open Innovation: In their seminal work, Chesborough et al. [10] divide open innovation into two conceptually different dimensions: inbound or outside-in open innovation and outbound or inside-out open innovation. Quite similar to this dimensionalizing of open innovation, Dahlander et al. [13] reviewed 150 papers published on open innovation in the ISI database and concluded that there are two types of open innovation: inbound and out-bound open innovation.

Inbound or Outside-In Open Innovation: In-bound or outside-in open innovation refers to the use of discoveries of others and involves opening up to and establishing relationships with external organisations with the purpose to access their technical and scientific competences for improving the firm's innovation performance. According to Dahlander \& Gann [13], the inbound innovation entails two processes termed sourcing and acquiring. Sourcing refers to how firms can use external sources of innovation after they scan the external environment for possible ideas and technologies. Acquiring is defined as acquiring inputs to the innovation process through the market place. This can happen through licensing-in and acquiring expertise from the external environment. Sourcing is non-pecuniary in nature and may not bring any direct financial benefits to a firm while acquiring is pecuniary and is undertaken with profit-making in mind. Based on an empirical database of 124 firms, Gassmann \& Enkel [14] concluded that the inside-out dimension of open innovation enriches a company's knowledge base and innovative capabilities due to greater integration of suppliers, customers and external knowledge sources.

Outbound or Inside-Out Open Innovation: Out-bound or inside-out dimension implies that companies can look for external organisations with business models better suited to exploit and commercialise a particular technology than just depend on internal paths to market [10]. The external exploitation of ideas can happen in different markets by selling intellectual property rights and multiplying technology by diverting ideas to the external environment [14]. The aim however remains to exploit better innovation opportunities. In addition, out-bound open innovation involves opening up the innovation process for technology exploitation and outward technology [15]. Like in-bound open innovation, out-bound innovation also involves two processes which are revealing and selling. Revealing as the name suggests refers to how internal resources are revealed to the external environment without the firm hoping for any immediate financial rewards and seeking indirect benefits only. Thus revealing is non-pecuniary in nature. Selling implies how firms accrue befefits by commercialising their inventions and technologies through selling or licensing out to other firms [13]. Selling therefore is pecuniary in nature and is undertaken for direct profit to the firm.

Although firms may adopt both the dimension of open innovation, that is in-bound and out-bound; however, research seems to suggest that the out-bound processes of open innovation may not be as widespread as the in-bound processes [16]. Moreover, in addition to these two dimensions, Gassmann \& Enkel [14] identified a third dimension which they called "the coupled process" and defined as a process that links outside-in and inside-out processes of open innovation by working in alliances with complementary companies involving give and take as crucial elements of success. However, not many researchers have written about this dimension/process of open innovation.

Managerial Ties: Managerial ties are defined as "executives' boundary-spanning activities and their associated interactions with external entities" [17]. Managerial ties form a part of social capital or social exchange. Social capital, according to Adler and Kwon [18] is "roughly understood as the goodwill that is engendered by the fabric of social relations and that can be mobilized to facilitate action". Social capital acts as a powerful factor to explain actors' relative success in a number of organizational arenas. Adler and Kwon [18] cite a number of studies showing the effect of social capital on career success, executive compensation, job search, in obtaining richer pool of recruits for firms, facilitating inter-unit resource exchange and product innovation, creating intellectual capital, cross-functional team effectiveness, reducing turnover and organizational dissolution rates, facilitating entrepreneurship, helping in 
formation of start-up companies, strengthening supplier relations, regional production networks and improving inter-firm learning. Ties of managers may thus work wonders for a manager and the firm employing such a manager.

Managerial ties have been found to impact organizational performance both conceptually and empirically [5, 19-21]. Luo \& Chen [21] found empirically that the managerial ties have a profound and positive impact on firm efficiency and growth ${ }^{1}$. The social network theory states that managers with better interpersonal connections tend to earn more income, get more frequent promotions and have better careers [19]. This implies that firms value managerial ties and reward such interpersonal connections. In transition economies due to the lack of market supporting institutions, managers are often required to perform even basic functions like obtaining market information, interpreting regulations and enforcing contracts [22]. In view of this, ties of managers can play an important role in facilitating economic exchanges and hence improve firm performance [23].

The role of managerial ties becomes more important in uncertain times and in transition economies which are less regulated and lack market supporting institutions like clear laws and regulations [5]. A look at the related literature reveals that a lot of work on managerial ties has been done in emerging economies where uncertainty is higher. In case of weak institutional support and information distortion typical of imperfect competition, the social capital embedded in managerial ties becomes important whereby a well-connected manager exhibits entrepreneurial spirit and adds value by networking with others [5, 24]. Such social capital is not only valuable but unique and an intangible resource which becomes difficult to replicate, thus giving firms possessing such ties a significant advantage against competitors [25].

Luo \& Chen [21] explore managerial ties in China and found two types of managerial ties: one, ties with managers at other firms such as suppliers, buyers and even competitors; two, ties with government officials. The benefits of managerial ties are many, both for the individuals and the businesses. Managers reputed for trust and good relationships are able to acquire resources for themselves, their businesses and their friends and family. Such managers are able to work more efficiently as they can avoid procedures and processes, get expedient approvals and receipt of permits. They also receive bonuses, commissions, kickbacks from sales, stocks or options, promotions, new job offers, better career advancement opportunities, attract funds from domestic and foreign sources and win government projects, build customer networks quickly and develop efficient markets channels. Managerial ties can also help in exchange of information like news, trade secrets, competitor information and enable access to new technology and innovation. Managerial ties benefit the managers as enterprises prefer to employ those people who have wide relationships with government, other institutions and customers. Employing such managers makes it easy for the firms to get favorable policies, changes in laws, access to unobtainable or scarce resources like land, loans, beneficial treatment in sales and purchases for the day-today operations and so on [18].

Besides ties with managers at other firms and ties with government officials, managers also forge ties with researchers in universities and other research centers. These ties are also important to enhance the output of open innovation. Given the benefits it offers in stimulating R\&D activities in firms, the university-industry collaboration has been in place for a long time. The role played by university-industry linkages in spurring R\&D activities in firms is well documented [26]. Laursen and Salter [27] found that firms have a higher probability of considering university knowledge while searching for external knowledge sources. On the basis of the above discussion we propose that:

Proposition 1a: These three types of managerial ties positively affect the outcomes in the open innovation paradigm.

Proposition 1b: These three types of managerial ties negatively affect the outcomes in the open innovation paradigm.

Moderating Effect of Regimes of Appropriability: Appropriability is defined as the the ability of the owner of a resource to receive a return equal to the value created by that resource [28, 29]. Appropriability is also "the ability of different stakeholders to retain for themselves the financial benefits that arise through the exploitation of an innovation" [30]. If the firm that creates innovation is the main beneficiary of the innovation, the situation is called 'strong appropriability regime' and if the creator of innovation gains less than other stakeholders, it is referred to as 'weak appropriability regime'.

Strong regimes of appropriability are generally characterized by tacit knowledge and strong legal protection while codified knowledge and weak legal protection are the features of weak regimes of 
appropriability [31]. This relation is quite similar to the relationship between managerial ties and firm performance in transition and developed economies. In transition economies, managerial relations may be necessary to develop in order to gain institutional advantage and superior performance. As opposed to this, developed economies generally exhibit the characteristics of strong regimes of appropriability wherein advantages are based on some intangible assets [32] and laws and regulations are strong. Thus in economies with proper market supporting institutions like clear laws and regulations [5], strong appropriability regimes are expected to exist and thus knowledge spillovers are low and investments in potential innovations are likely to be high as investors expect positive returns. On the other hand, under weak appropriability regimes as may be expected in transition economies, since knowledge spillovers are high [33], investors would be skeptical about the returns and thus investments in projects related to innovation are likely to be low.

In addition, under strong appropriability regimes, firms will choose to patent their innovations in order to deter imitation by rivals and protect their revenue streams [34]. Under weak appropriability regimes, as obtaining patents, copyrights, etc requires some disclosure of enabling knowledge to the parties concerned [34] and since patents and copyright laws frequently fail to ensure the degree of protection they were intended to afford [30], firms may use isolating mechanisms like adopting secrecy in routines and operations to obstruct imitation and derive benefits from open innovations [35]. Hence, in a fully protected innovation environment (strong appropriability conditions), full disclosure poses no risk of unauthorized imitation, but with limited protection (weak appropriability conditions), disclosure risks imitation [34].

Recceing the appropriability conditions of an industry can help determine its favorableness for innovation. However, according to Harabi (1995), measuring appropriability is difficult because of the lack of a "theoretically sound" and an "empirically precise" method of measuring the private and social returns of innovation. Nonetheless, some means of judging appropriability conditions, brought forth due to the efforts of many researchers, are: patents, secrecy, lead time, moving quickly down the learning curve, superior sales or service efforts, making imitation more difficult for competitors, economies of scale, national advertisement and national distribution [36, 37]. These have been broadly divided into three groups: a) patents, b) secrecy and c) lead time and related advantages [38].

There is hardly a study about how appropriability conditions affect the relationship between managerial ties and open innovation. Can appropriability conditions skittle the creation of open innovation even in presence of good managerial ties and other factors? How effective are appropriability conditions in successful open innovation? Dosi et al. [39] broadly conclude that appropriability conditions in general have only limited effects on the pattern of (closed) innovation. Given this dichotomy between the results of several different studies on innovation, this research aims to address the moderating role of strong and weak appropriability conditions between managerial ties and the creation of successful open innovation. Therefore, based on the above discussion, we propose that:

Proposition 2a: Ceteris paribus, under strong regimes of appropriability, a positive relationship exists between managerial ties and the creation of open innovation because firms are able to protect their intellectual property.

Proposition 2b: Ceteris paribus, under weak regimes of appropriability, a negative or weak relationship exists between managerial ties and creation of open innovation because of broader scope for imitation of innovation.

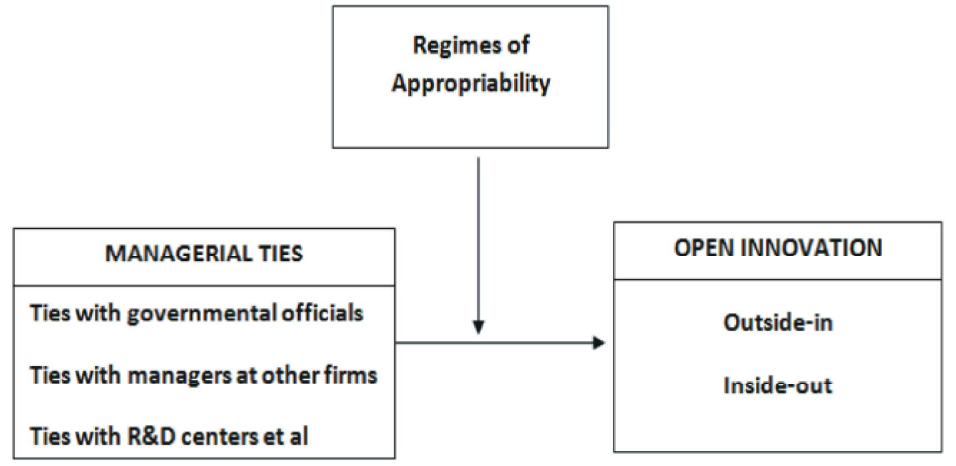

Fig. Conceptual framework 


\section{DISCUSSION}

This conceptual paper discussed the relationship between managerial ties and open innovation and how this relationship can be affected in different appropriability regimes. Knowledge management is important for organizations to improve their performance [51]. The open innovation model regards $R \& D$ as an "open system" in which ideas can come from both inside and outside of the organization and can go to the market through similar channels [10]. Thus open innovation also refers to the innovation process in which the boundaries of the firm are porous [1]. This is often a result of an alliance or collabration or any such agreement between firms and since the knowledge is distributed, the innovation process is also distributed among the players involved in this process [40]. As the boundaries become porous, there is more interaction between partner firms that results in greater technology acquisition and exploitation [41]. As a result there is a greater amount of resources and expertise at hand than expected in a closed innovation model. This has many benefits, one of which is faster innovations.

On the issue of ties, networking at the firm level can enhance a firm's competitive advantage by providing access to resources of other network members which can help in entering markets that involve a firm's core technologies and competencies [42]. However, if the aim of networking is creation of innovation, such a process entails several challenges. This is because the participating firms may require entering into relationships with universities and research institutions [43], suppliers [44] and users [45, 46]. A firm can face challenges in its open innovation endeavors right from the stage of exploring the possible networking partners up to the exploitation stage and even beyond. In case of open innovation, firms rely on an extensive use of interorganizational relationships to internalize external ideas from a variety of external innovation sources and to market the ideas that are developed within the firm but fall outside the firm's current business model (Chesbrough, 2006). Such firms search for new ideas and technologies by increasing the search breath (the number of external sources they rely upon in their innovative activities) and the search depth (the extent to which firms draw deeply from the different external sources) of their innovation networks [47]. The purpose of this could either be to use the inter-organizational relationship for explorative or exploitative purpose [48]. In the open innovation paradigm, given the diversity of partners, the activities of acquisition, assimilation, transformation and exploitation [35] become all the more complex. This is where the role of well-connected managers and managerial ties becomes paramount. Managerial relations with different actors can help sail a firm smoothly by making easier the exploration and exploitation of external sources of knowledge. Apart from managerial ties, appropriability conditions in an industry influence a firm's choice for external collaborations for innovation. Regime of appropriability or the extent to which a company can protect its innovative capabilities influences heavily a firm's choice of strategic technology alliances, mergers and acquisitions and mixed strategies [49]. Regimes of appropriability can also decide whether firms in a particular setting should enter the open innovation paradigm or continue to rely on internal R\&D.

Conclusion, Implications and Future Research: This paper discussed the relationship between managerial ties and open innovation and how this relation can be affected by appropriability regimes. We propose in this conceptual paper that a positive relation exists between managerial relations and open innovation. In other words, ties of managers of a firm with managers at other firms, government officials and researchers at universities and research centers enhance the outcomes of open innovation. Secondly, we take into consideration the effect of regimes of appropriability and posit that a positive relationship exists between managerial ties and open innovation under strong appropriability regimes. This is to say that the outcomes of open innovation can be enhanced if in addition to good managerial ties a firm is also operating under strong appropriability regimes. The implications of this study spread into the practitioners' domain and can help firms decide whether it is useful for their managers to invest in managerial ties or is investing in such relationships unworthy of the investment [50]. Additionally studying the regimes of appropriability becomes imperative while operating in the open innovation paradigm as not doing so may yield negative results even in presence of managerial ties. Lastly this study leaves enough room for future empirical research and testing of the propositions developed above. It would be interesting to find out empirically in different industry and country settings how these variables operate to affect the creation of open innovation. 


\section{Endnotes:}

- $\quad$ Luo and Chen (1997) use the Chinese word guanxi which refers to the concept of drawing on connections or networks to secure favors in personal or business relations.

\section{REFERENCES}

1. Chesbrough, H., 2005. Open innovation: The new imperative for creating and profiting from technology. Harvard Business Press.

2. Moffat, L. and N. Archer, 2004. Knowledge management in production alliances. Information Systems and e-Business Management, 2(2): 241-267.

3. Love, P., et al., 2002. A model for supporting inter organizational relations in the supply chain. Engineering Construction and Architectural Management, 9(1): 2-15.

4. Shaw, M., 2000. Building an e-business from enterprise systems. Information Systems Frontiers, 2(1): 7-17.

5. Peng, M.W. and Y.D. Luo, 2000. Managerial ties and firm performance in a transition economy: The nature of a micro-macro link. Academy of Management Journal, 43(3): 486-501.

6. Acquaah, M., 2007. Managerial social capital, strategic orientation and organizational performance in an emerging economy. Strategic Management Journal, 28(12): 1235-1255.

7. Yeo, R.K., 2005. Learning: The Secret of the Art of War. Management Research News, 28(8).

8. González-Álvarez, N. and M. Nieto-Antolín, 2007. Appropriability of innovation results: An empirical study in Spanish manufacturing firms. Technovation, 27(5): 280-295.

9. Huizingh, E., 2010. Open innovation: State of the art and future perspectives. Technovation.

10. Chesbrough, H., W. Vanhaverbeke and J. West, 2006. Open innovation: Researching a new paradigm. Oxford University Press, USA.

11. Chesbrough, H., 2003. The era of open innovation. MIT Sloan Management Review, pp: 44.

12. Govindarajan, V. and C. Trimble, 2005. 10 Rules for Strategic Innovators. Audio-Tech Business Book Summaries, Inc.

13. Dahlander, L. and D. Gann, 2010. How open is innovation? Research Policy, 39(6): 699-709.

14. Gassmann, O. and E. Enkel, 2004. Towards a theory of open innovation: three core process archetypes. Citeseer.
15. Lichtenthaler, U., 2009. Outbound open innovation and its effect on firm performance: examining environmental influences. R\&D Management, 39(4): 317-330.

16. Chesbrough, H. and A.K. Crowther, 2006. Beyond high tech: early adopters of open innovation in other industries. R\&D Management, 36(3): 229-236.

17. Geletkanycz, M.A. and D.C. Hambrick, 1997. The external ties of top executives: Implications for strategic choice and performance. Administrative Science Quarterly, 42(4).

18. Adler, P.S. and S.W. Kwon, 2002. Social capital: Prospects for a new concept. The Academy of Management Review, 27(1): 17-40.

19. Granovetter, M., 1985. Economic Action and Social Structure: The Problem of EmbeddednessÕ. American J. Sociology, 91(3): 481-510.

20. Xin, K.R. and J.L. Pearce, 1996. Guanxi: Connections as Substitutes for Formal Institutional Support. The Academy of Management Journal, 39(6): 1641-1658.

21. Luo, Y. and M. Chen, 1997. Does guanxi influence firm performance? Asia Pacific J. Management, 14(1): 1-16.

22. Khanna, T. and K. Palepu, 1997. Why focused strategies may be wrong for emerging markets. Harvard Business Review, 75(4): 41-48.

23. Peng, M.W. and P.S. Heath, 1996. The growth of the firm in planned economies in transition: Institutions, organizations and strategic choice. Academy of Management Review, 21(2): 492-528.

24. Burt, R.S., 1997. The contingent value of social capital. Administrative Science Quarterly, 42(2).

25. Tsang, E.W.K., 1998. Can guanxi be a source of sustained competitive advantage for doing business in China? The Academy of Management Executive (1993-2005), 12(2): 64-73.

26. Rasiah, R. and C.V.G.R. Govindaraju, 2009. University-industry R\&D collaboration in the automotive, biotechnology and electronics firms in Malaysia.

27. Laursen, K. and A. Salter, 2004. Searching low and high: what types of firms use universities as a source of innovation. Research Policy, 33(8): 1201-1215.

28. Teece, D.J., 1987. Profiting from technological innovation: Implications for integration collaborations, licensing and public policy, in The Competitive Challenge., D.J. Teece, Editor. Ballinger, Cambridge, MA.

29. Levin, R., et al., 1987. Appropriating the returns from industrial research and development. Brookings papers on economic activity, 3: 783-831. 
30. Atkins, M.H., 1998. The role of appropriability in sustaining competitive advantage--an electronic auction system case study. The Journal of Strategic Information Systems, 7(2): 131-152.

31. Hurmelinna, P., K. Kyläheiko and T. Jauhiainen, 2007. The Janus face of the appropriability regime in the protection of innovations: Theoretical re-appraisal and empirical analysis. Technovation, 27(3): 133-144.

32. Sim, A. and J.R. Pandian, 2003. Emerging Asian MNEs and their internationalization strategies-Case study evidence on Taiwanese and Singaporean firms. Asia Pacific J. Management, 20(1): 27-50.

33. Kafouros, M.I. and P.J. Buckley, 2008. Under what conditions do firms benefit from the research efforts of other organizations? Research Policy, 37(2): 225-239.

34. Anton, J. and D. Yao, 2004. Little patents and big secrets: Managing intellectual property. The RAND J. Economics, 35(1): 1-22.

35. Zahra, S.A. and G. George, 2002. Absorptive capacity: A review, reconceptualization and extension. The Academy of Management Review, 27(2): 185-203.

36. Harabi, N., 1995. Appropriability of technical innovations an empirical analysis. Research Policy, 24(6): 981-992.

37. López, L.E. and E.B. Roberts, 2002. First-mover advantages in regimes of weak appropriability: the case of financial services innovations. J. Business Res., 55(12): 997-1005.

38. Scherer, F. and D. Ross, 1992. Industrial market structure and economic performance. Boston, MA.

39. Dosi, G., L. Marengo and C. Pasquali, 2006. How much should society fuel the greed of innovators?: On the relations between appropriability, opportunities and rates of innovation. Research Policy, 35(8): 1110-1121.

40. Acha, V. and L. Cusmano, 2005. Governance and coordination of distributed innovation processes: patterns of R\&D co-operation in the upstream petroleum industry. Economics of Innovation and New Technol., 14(1-2): 1-21.
41. Chesbrough, H., 2006. The era of open innovation in Managing innovation and change, D. Mayle, Editor. Sage Publications.

42. Thorelli, H.B., 1986. Networks: Between Markets and Hierarchies. Strategic Management J., 7(1): 37-51.

43. Perkmann, M. and K. Walsh, 2007. Universityindustry relationships and open innovation: Towards a research agenda. International J. Management Reviews, 9(4): 259-280.

44. Emden, Z., R.J. Calantone and C. Droge, 2006. Collaborating for new product development: selecting the partner with maximum potential to create value. J. Product Innovation Management, 23(4): 330-341.

45. Von Hippel, E., 2001. Innovation by user communities: Learning from open-source software. Mit Sloan Management Review, 42(4): 82-86.

46. Von Hippel, E. and R. Katz, 2002. Shifting Innovation to Users via Toolkits. Management Sci., 48(7): 821-833.

47. Laursen, K. and A. Salter, 2006. Open for innovation: The role of openness in explaining innovation performance among UK manufacturing firms. Strategic Management J., 27(2): 131-150.

48. March, J.G., 1991. Exploration and exploitation in organizational learning. Organization Sci., 2(1): 71-87.

49. Hagedoorn, J. and G. Duysters, 2002. External sources of innovative capabilities: the preference for strategic alliances or mergers and acquisitions. J. Management Studies, 39(2): 167-188.

50. Warren, D.E., T.W. Dunfee and N. Li, 2004. Social exchange in China: The double-edged sword of Guanxi. J. Business Ethics, 55(4): 353-370.

51. Muhammad, N., et al., 2011. Knowledge Management Practices (KMP) and Academic Performance in Universiti Teknologi Mara (UITM) Terengganu, Malaysia. World Applied Sciences Journal, 12(Special Issue): 21-26. 